\title{
Early Post Endoscopic Retrograde Cholangiopancreatography (ERCP) Cholecystitis - Incidence, Risk Factors, Severity, and Surgical Implications - Case Series
}

\author{
Ravikiran SK*, Nitin Rao AR**, Lokesh $L V^{*}$, Avinash $B^{*}$, Manjunath Patil , \\ Kiran $R^{*}$, Satyaprakash $B S^{*}$ \\ *Department of Gastroenterology, MS Ramaiah Medical College, Bengaluru-560054, India \\ ${ }^{* *}$ Department of Surgical Gastroenterology, MS Ramaiah Medical College, Bengaluru-560052, India
}

\begin{abstract}
Corresponding author:
Nitin Rao AR. Department of Surgical Gastroenterology, MS Ramaiah Medical College, Bengaluru, India. Phone:+91-9880462155.E-mail: nitrao@gmail.com
\end{abstract}

\begin{abstract}
Cholecystitis can be a serious complication following endoscopic retrograde cholangiopancreatography (ERCP). Though the concept of early post-ERCP cholecystitis (PEC) is well known, studies that analysed the predictors, occurrence and outcomes of early PEC are rare. This is an analysis of 11 cases developing severe early post-ERCP cholecystitis.
\end{abstract}

Keywords: Choledocholithiasis, liver abscess, endoscopic retrograde cholangiopancreatography

\section{ABSTRAK}

Kolesistitis dapat menjadi komplikasi serius setelah pemeriksaan endoskopik retrograde cholangiopancreatography (ERCP). Meskipun konsep awal kolesistitis pasca-ERCP (PEC) sudah banyak diketahui, namun penelitian yang menganalisis prediktor, kejadian dan hasil dari PEC awal masih sedikit. Laporan kasus ini adalah analisis dari 11 kasus yang berkembang menjadi kolesistitis yang parah pasca-ERCP.

Kata kunci: Choledocholithiasis, abses hepar, endoscopic retrograde cholangiopancreatography (ERCP)

\section{INTRODUCTION}

Endoscopic retrograde cholangiopancreatography (ERCP) is a commonly performed diagnostic procedure for pancreaticobiliary disorders. Indications for ERCP procedure include obstructive jaundice and diseases of biliary or pancreatic ductal system which need treatment or tissue sampling. Other indications of ERCP include nasobiliary drinage, manometry for Sphincter of Oddi, biliary stenting for strictures and leakage, etc.

ERCP procedure requires skill and expertise on the part of gastroenterologist/surgeon to minimize the procedure related complications. Post ERCP complication rates vary widely depending on the complexity of the intervention and the individual case. ERCP is associated with post procedure complications such as pancreatitis, bleeding, sepsis and perforation.

Cholecystitis complicates about 0.2 to $0.5 \%$ of ERCPs. ${ }^{1}$ Gallbladder (GB) stones and filling of the gallbladder with contrast during ERCP are known to be associated with this risk. The risk of cholecystitis increases due to placement of self-expandable metal stents, particularly if cystic duct is obstructed. ${ }^{2}$ The aim of this study was to assess the incidence, severity and risk factors associated with early PEC. 


\section{CASE ILLUSTRATION}

A total of 398 patients underwent ERCP for various indications between June 2016 and May 2017 and only 11 patients ( 5 men and 6 women) developed severe early PEC. Incidence of early acute severe cholecystitis following ERCP was $2.77 \%$. Mean age of the cases was 53 years (ranged between 31 and 68 years). Duration to develop PEC ranged between 2 and 30 days. Criteria for a diagnosis of PEC was finding of either one or more of the following on surgery/ histopathology: empyema, gangrenous gall bladder or severe cholecystitis on histopathology of the gall bladder specimen.

As can be seen in the Table 1, 10 out of 11 patients had evidence of choledocholithiasis during ERCP while one patient showed mid and lower common bile duct (CBD) stricture.

GB was not opacified in 7 patients. CBD stent was placed in all of them. At presentation of PEC, the mean levels of total bilirubin $(2.31 \mathrm{mg} / \mathrm{dL})$ and total leukocyte $(13,800 \mathrm{cells} / \mathrm{cmm})$ were above normal while protein $(7.2 \mathrm{~g} / \mathrm{dL})$ and albumin $(3.5 \mathrm{~g} / \mathrm{dL})$ remained normal. While one patient had sub-total cholecystectomy $(9.09 \%)$, the rest underwent complete cholecystectomy. Major finding during cholecystectomy were empyema (5 patients), stone in the neck of GB (4 patients) and in cystic duct (2 patients), liver abscess and gangrenous GB (3 patients each). Cholecystectomy surgeries were also complicated due to difficulty in identifying Calot's cysto-hepatic triangle and presence of complex adhesions. There was no reported mortality.

\section{DISCUSSION}

ERCP is a routinely done interventional procedure for various pancreatico-biliary conditions. It is however associated with complications like haemorrhage, pancreatitis, cholangitis and cholecystitis. The incidence of various complications with ERCP is reported to be $9.7 \%$ with a mortality rate of $0.7 \% .{ }^{3}$ PostERCP cholecystitis (PEC) is rare with incidence of $1.35 \%{ }^{4}$ It is seen associated with filling of the GB with contrast during ERCP in the presence of GB stones. Iatrogenic intramural dissection of the gallbladder wall can mimic PEC. Diagnosis and treatment of PEC should be as per the clinical guidelines established for management of cholecystitis. ${ }^{5}$

Incidence of early severe PEC in our study was found to be $2.77 \%$ which is higher than that is reported in the literature. ${ }^{4}$ Cholecystitis can occur within two weeks of ERCP. ${ }^{4}$ In our series the duration to develop PEC was from two to 30 days. Chronic cholecystitis, gallbladder opacification, previous acute pancreatitis, high leukocyte count and biliary stent placement ERCP are considered as risk factors for PEC occurrence within two weeks of ERCP. ${ }^{4}$ Interestingly, more than half of our patients had no opacification of GB but all of them had plastic CBD stent placed. In our series, more than half of the cases had stone either in the neck or in the cystic duct. This is similarly to few case reports which showed stones in neck of GB leading to PEC. ${ }^{6}$ This may indicate that multiple factors may lead to PEC.

Similar to published literature, choledocholithiasis was the main indication for ERCP in our series. As expected, at presentation of early PEC there were changes in total bilirubin and total leukocyte count in our series. ${ }^{4}$ We had a much higher rate of subtotal cholecystectomy $(9.09 \%)$ especially in males as consistent with published literature. ${ }^{8}$ Another interesting finding in the study has been that subtotal cholecystectomies for acute cholecystitis are performed at higher rates in teaching hospitals which we happen to be as well. ${ }^{8}$

This case series has led to change in practice at our institute while performing ERCP and diagnosing post

Table 1. Patient demographics, ERCP findings, surgical findings and surgery performed

\begin{tabular}{|c|c|c|c|c|c|c|}
\hline No & Sex & Age & ERCP Findings & $\begin{array}{l}\text { Time to } \\
\text { cholecystitis } \\
\text { from ERCP }\end{array}$ & Intraoperative findings & Surgery performed \\
\hline 1 & $\mathrm{M}$ & 62 & GB not opacified, mid \& lower CBD stricture & 30 days & Stone in GB neck, empyema, liver abscess & $\begin{array}{l}\text { Sub-total cholecystectomy, } \\
\text { abscess drainage }\end{array}$ \\
\hline 2 & M & 50 & Choledocholithiasis, GB not opacified & 30 days & Impacted stone in GB neck, empyema & Cholecystectomy \\
\hline 3 & $\mathrm{~F}$ & 55 & Choledocholithiasis, GB not opacified & 2 days & $\begin{array}{l}\text { Gangrenous GB, liver abscess, } \\
2 \text { stones in GB neck }\end{array}$ & Cholecystectomy \\
\hline 4 & $\mathrm{~F}$ & 31 & Choledocholithiasis, GB not opacified & 4 days & Stones in cystic duct, empyema & Cholecystectomy \\
\hline 5 & $\mathrm{~F}$ & 59 & Choledocholithiasis & 4 days & Adhesions, Empyema, dilated cystic duct & Cholecystectomy \\
\hline 6 & M & 53 & Choledocholithiasis, GB not opacified & 5 days & Adhesions, empyema & Cholecystectomy \\
\hline 7 & $\mathrm{~F}$ & 37 & Coledocholithiasis, GB not opacified & 2 days & Stone in cystic duct & Cholecystectomy \\
\hline 8 & $M$ & 64 & Choledocholithiasis & 14 days & Gangrenous GB & Cholecystectomy \\
\hline 9 & $\mathrm{~F}$ & 68 & Choledocholithiasis & 30 days & Adhesions & Cholecystectomy \\
\hline 10 & $\mathrm{~F}$ & 45 & Choledocholithiasis & 7 days & Adhesions & Cholecystectomy \\
\hline 11 & M & 60 & Cholelithiasis, GB not opacified & 14 days & $\begin{array}{l}\text { Liver abscess, stone in GB neck } \\
\text { gangrenous GB }\end{array}$ & $\begin{array}{l}\text { Cholecystectomy \& abscess } \\
\text { drainage }\end{array}$ \\
\hline
\end{tabular}

GB: gall bladder; CBD: common bile duct, ERCP: endoscopic retrograde cholangiopancreatography 
ERCP complications especially PEC. We attempt to document in detail the amount of contrast injected and opacification of GB and cystic duct and we do not place CBD stent unless absolutely necessary. In symptomatic patients post ERC, we have very low threshold to get imaging (contrast-enhanced computed tomography) irrespective of duration of presentation. We also follow patients closely for the need of early operative surgery and are not wary of converting laparoscopic to open surgery and to a subtotal cholecystectomy as well.

Early severe cholecystitis can be a life threatening complication post ERCP. Early recognition and immediate intervention may help minimize morbidity and mortality related with this complication. ${ }^{9}$ Reviewing the complications as part of a quality improvement method may aid in educating endoscopists, help reduce the risks in future post procedure complications, and enhance the complete quality of ERCP. ${ }^{10}$ We would caution surgeons to be aware of the possibility of this entity, severe post ERCP cholecystitis and would recommend a subtotal cholecystectomy as a safer alternative procedure in this scenario and would advise them to counsel patients and obtain consent for the same preoperatively.

Financial Support and Sponsorship: Nil

Conflicts of interest: We declare no conflicts of interest

\section{REFERENCES}

1. Anderson MA, Fisher L, Jain R, Evans JA, Appalaneni V, Ben-Menachem T, et al. Complications of ERCP. Gastrointest Endosc 2012;75:467-73.

2. Chandrasekhara V, Khashab MA, Muthusamy VR, Acosta RD, Agrawal D, Bruining DH, et al. Adverse events associated with ERCP. Gastrointest Endosc 2017;85:32-47.

3. Kochar B, Akshintala VS, Afghani E, Elmunzer BJ, Kim KJ, Lennon AM, et al. Incidence, severity, and mortality of postERCP pancreatitis: a systematic review by using randomized, controlled trials. Gastrointest Endosc 2015;81:143-9.

4. Cao J, Peng C, Ding X, Shen Y, Wu H, Zheng R, et al. Risk factors for post-ERCP cholecystitis: a single-center retrospective study. BMC Gastroenterol 2018;18:128.

5. Wojda T, Nuschke J, Smith E, Schadt S, Strosberg D, Geme B, et al. Endoscopic retrograde cholangiography: complications, emergencies, and related topics. Int J Acad Med 2018;4:124.

6. Shields HM, Sidhu H. Two cases of acute cholecystitis and symptomatic choledocholithiasis in two women less than 40-years-of-age with hormonal intrauterine devices. Case Rep Gastrointest Med 2018;2018:2390213.

7. Saito H, Kakuma T, Kadono Y, Urata A, Kamikawa K, Imamura $\mathrm{H}$, et al. Increased risk and severity of ERCP-related complications associated with asymptomatic common bile duct stones. Endosc Int Open 2017;05:E809-17.

8. Sabour AF, Matsushima K, Love BE, Alicuben ET,
Schellenberg MA, Inaba K, et al. Nationwide trends in the use of subtotal cholecystectomy for acute cholecystitis. Surgery 2020;167:569-74.

9. Dumonceau JM, Kapral C, Aabakken L, Papanikolaou IS, Tringali A, Vanbiervliet G, et al. ERCP-related adverse events:European Society of Gastrointestinal Endoscopy (ESGE) Guideline Endoscopy 2020;52:127-49.

10. Szary NM, Al-Kawas FH. Complications of endoscopic retrograde cholangiopancreatography: how to avoid and manage them. Gastroenterol Hepatol (N Y) 2013;9:496-504. 